\title{
ГОМЕОПАТІЯ ЯК МЕТОД НАДАННЯ МЕДИЧНОЇ ДОПОМОГИ РІЗНИМ КАТЕГОРІЯМ НАСЕЛЕННЯ: ОЦІНКА ЛІКАРІВ
}

\author{
${ }^{1}$ Національна медична академія післядипломної освіти ім. П.Л. Шупика, м. Київ, Україна \\ ${ }^{2}$ Вінницький національний медичний університет ім. М.І. Пирогова, Україна
}

Мета: проаналізувати думку лікарів щодо ефективності застосування гомеопатії у наданні медичної допомоги.

Матеріали і методи. Дослідження проведено з використанням методів системного підходу і системного аналізу та медико-статистичного методу. За спеціально розробленими анкетами було опитано лікарів різних спеціальностей. Опрацьовано 139 якісно заповнених анкет.

Результати. Встановлено задоволеність лікарів гомеопатією як методом надання медичної допомоги. Більшість респондентів відмітили ефективність цього методу $(88,5 \% \pm 3,4 \%)$, понад половина застосовують його у своїй

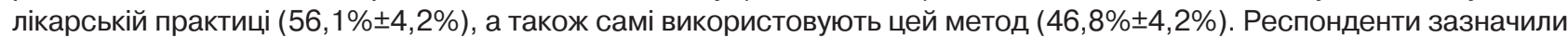
ефективність методу гомеопатії як при лікуванні гострих та хронічних захворювань, так і при застосуванні його з метою профілактики.

Висновки. Системне впровадження методу гомеопатії може сприяти суттєвому підвищенню ефективності, якості, безпечності та доступності медичної допомоги різним категоріям населення.

КЛЮЧОВІ СЛОВА: соціологічне дослідження, гомеопатія, лікар, ефективність медичної допомоги.

Здоров'ю людини належить пріоритетне місце серед людських потреб, тому проблема якості медичної допомоги сьогодні вважається актуальною для будь-якої системи охорони здоров'я. В Україні актуальність цієї проблеми посилюється у зв'язку із трансформацією медичної галузі $[1 ; 4 ; 6-9 ; 11 ; 13 ; 17 ; 19]$

Водночас ще у 1978 р. Всесвітня організація охорони здоров'я (ВООЗ) [13] підкреслювала необхідність інтегрувати нетрадиційну медицину у первинну медико-санітарну допомогу (ПМСД) національних систем охорони здоров'я з метою оптимізації якості профілактичної і лікувальної допомоги населенню. Актуальність інтеграції альтернативних методів лікування засвідчена і в такому документі, як «WHO Traditional Medicine Strategy: 2014-2023» [19]. Водночас нова концепція ВООЗ щодо якості системи охорони здоров'я має на меті перехід від орієнтованої на хворобу моделі до холістичного (цілісного) підходу до вирішення проблем пацієнта [5].

Однак ні в міжнародних, ні у вітчизняних фундаментальних дослідженнях проблем забезпечення якості медичної допомоги $[4 ; 6-9 ; 17]$ питання інтеграції гомеопатичного методу з метою іï оптимізації не розглядалося.

Водночас і фахівці ВООЗ, і ряд зарубіжних та вітчизняних вчених і лікарів підкреслюють доцільність ширшого використання гомеопатії у сучасній медичній практиці, зважаючи на безпечність, ефективність та економічну до-

() Н.Г. Гойда, Л.П. Гуцол, 2014 ступність гомеопатичних лікарських засобів [2;3;5;10;12;14;15;16;18;19].

Саме ці протиріччя визначили мету даного соціологічного дослідження.

Мета дослідження: проаналізувати думку лікарів щодо гомеопатії як методу надання медичної допомоги різним категоріям населення.

Матеріали і методи. Для проведення даного медико-соціологічного дослідження була розроблена програма, яка включала етапи визначення об'єкта і предмета дослідження, визначення генеральної сукупності і формування репрезентативної вибірки, розробку інструменту дослідження (анкети) [11], його апробацію і корекцію, збір, обробку та аналіз даних, оцінку результатів дослідження. Методом збору даних було безповоротне вибіркове анонімне письмове опитування (кожен респондент заповнював анкету лише один раз). Дослідження проведено з використанням методів системного підходу і системного аналізу та медико-статистичного методу.

Об'єктом дослідження була думка респондентів - лікарів Київської міської клінічної лікарні №1, Київської міської дитячої клінічної лікарні №2 і Київської міської шкірно-венерологічної лікарні. Отримано 147 анкет, з яких відібрано та опрацьовано 139 якісно заповнених анкет.

Розподіл респондентів за лікарською спеціальністю наведено на рис. 1.

Розподіл респондентів за кваліфікаційною категорією наведено у табл. 1.

Стаж роботи респондентів відображено в табл. 2. 


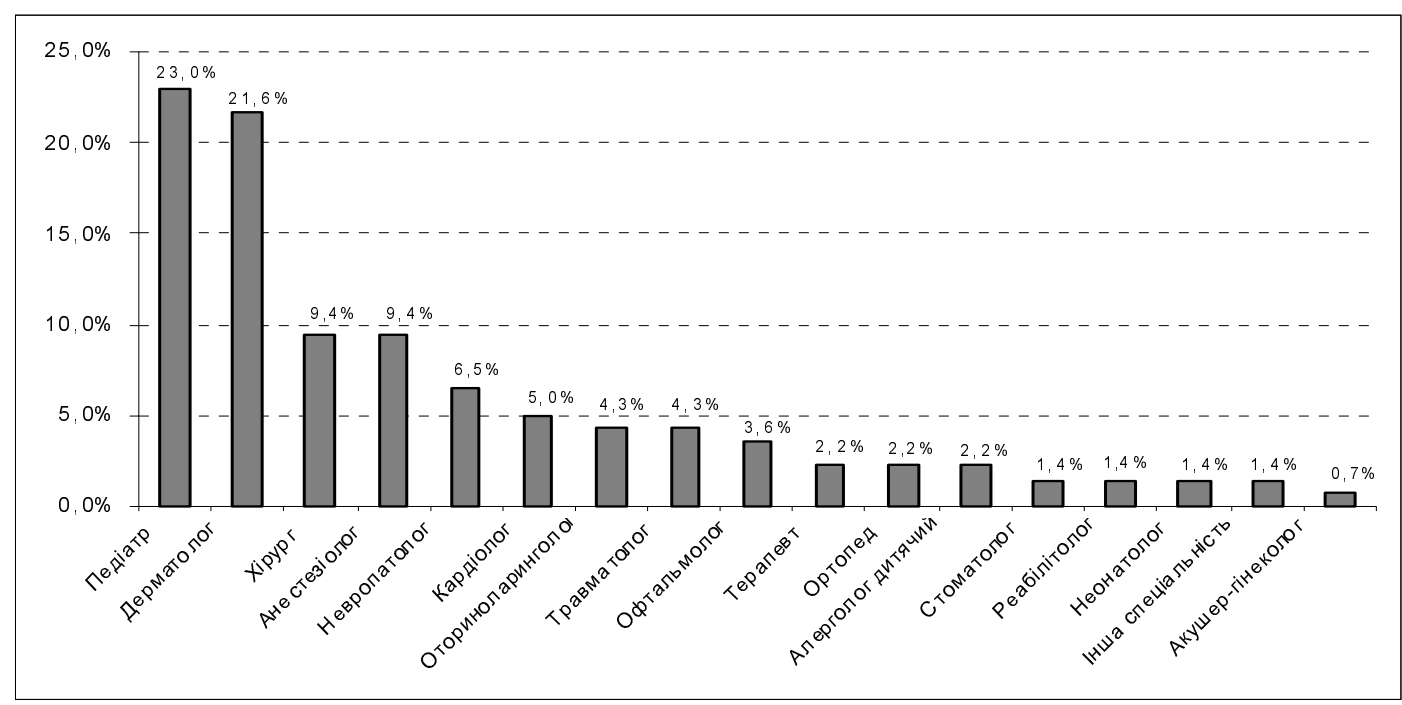

Рис. 1. Розподіл респондентів за лікарською спеціальністю

Таблиця 1. Кваліфікаційна категорія респондентів за лікарською спеціальністю

\begin{tabular}{|l|c|c|}
\hline \multicolumn{1}{|c|}{ Кваліфікаційна категорія } & Кількість респондентів & $\% \pm \mathrm{m}$ \\
\hline Вища & 77 & $55,4 \% \pm 4,2 \%$ \\
\hline Перша & 26 & $18,7 \% \pm 3,3 \%$ \\
\hline Друга & 15 & $10,8 \% \pm 2,6 \%$ \\
\hline Немає & 14 & $10,1 \% \pm 2,6 \%$ \\
\hline Не вказано & 7 & $5,0 \% \pm 1,9 \%$ \\
\hline
\end{tabular}

Таблиця 2. Стаж роботи респондентів

\begin{tabular}{|l|c|c|}
\hline \multicolumn{1}{|c|}{ Стаж роботи } & Кількість респондентів & $\% \mathrm{~m}$ \\
\hline До 5 років & 26 & $18,7 \% \pm 3,3 \%$ \\
\hline $6-10$ років & 18 & $13,0 \% \pm 2,8 \%$ \\
\hline $11-15$ років & 27 & $19,4 \% \pm 3,4 \%$ \\
\hline $16-20$ років & 27 & $19,4 \% \pm 3,4 \%$ \\
\hline $21-25$ років & 9 & $6,5 \% \pm 2,1 \%$ \\
\hline $26-30$ років & 17 & $12,2 \% \pm 2,8 \%$ \\
\hline 31 та більше & 12 & $8,6 \% \pm 2,4 \%$ \\
\hline Не вказано & 3 & $2,2 \% \pm 1,2 \%$ \\
\hline
\end{tabular}

Серед усіх респондентів, які брали участь у цьому дослідженні, було 3,6\% $1,6 \%$ (5 осіб) кандидатів медичних наук і 0,7\% $0,7 \%$ ( 1 особа) докторів медичних наук.

Результати дослідження та їх обговорення. Понад половина опитаних лікарів $(56,1 \% \pm 4,2 \%)$ застосовують метод гомеопатії у своїй лікарській практиці. Досвід використання цього методу у лікарській практиці у найбільшої кількості респондентів $(41,0 \% \pm 5,6 \%)$ становить $6-10$ років.

Із респондентів, які мають досвід застосування методу гомеопатії, 2,3\% $1,6 \%$ вважають цей метод високоефективним, 88,5\% $\pm 3,4 \%$ - ефективним $(p<0,001)$. Неефективним вважають метод гомеопатії 9,2\% $\pm 3,1 \%$ респондентів (рис. 2 ).
Результати вивчення думки респондентів щодо ефективності застосування методу гомеопатії у пацієнтів різних вікових груп наведено у табл. 3 .

Аналіз відповідей на запитання, чи доводилося респондентам самим використовувати метод гомеопатії для лікування, виявив, що 46,8\% $\pm 4,2 \%$ респондентів лікувалися методом гомеопатії, а $53,2 \% \pm 4,2 \%$ даний метод лікування особисто не застосовували.

Вивчення питання про використання гомеопатичного лікування родичами респондентів дозволило виявити факт застосування такого лікування в $59,0 \% \pm 4,2 \%$ випадків.

Крім того, встановлено, що 64,0\% $\pm 4,1 \%$ p $<0,001$ ) знайомих/колег по роботі опитаних лікарів ліку- 


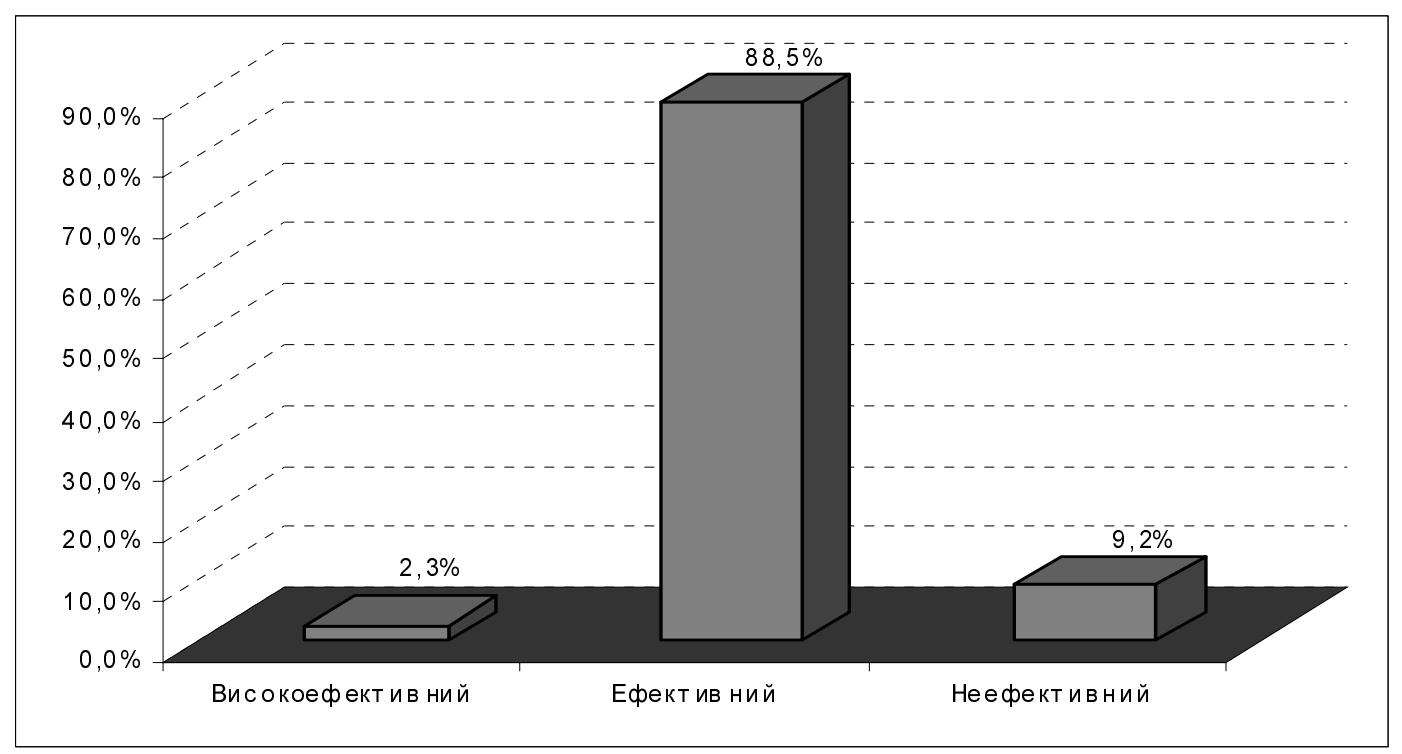

Рис. 2. Оцінка респондентами ефективності методу гомеопатії

Таблиця 3. Розподіл респондентів за відповідями щодо ефективності методу гомеопатії у різних вікових групах

\begin{tabular}{|l|c|c|}
\hline \multicolumn{1}{|c|}{ Вікова група населення } & Кількість респондентів & $\% \pm \mathrm{m}$ \\
\hline Діти & 37 & $42,5 \% \pm 5,3 \%$ \\
\hline Дорослі особи молодого віку & 15 & $17,2 \% \pm 4,0 \%$ \\
\hline Дорослі особи середнього віку & 11 & $12,6 \% \pm 3,6 \%$ \\
\hline Люди похилого віку & 7 & $8,1 \% \pm 2,9 \%$ \\
\hline Люди старечого віку & 1 & $1,2 \% \pm 1,1 \%$ \\
\hline Не залежить від віку & 28 & $32,2 \% \pm 5,0 \%$ \\
\hline
\end{tabular}

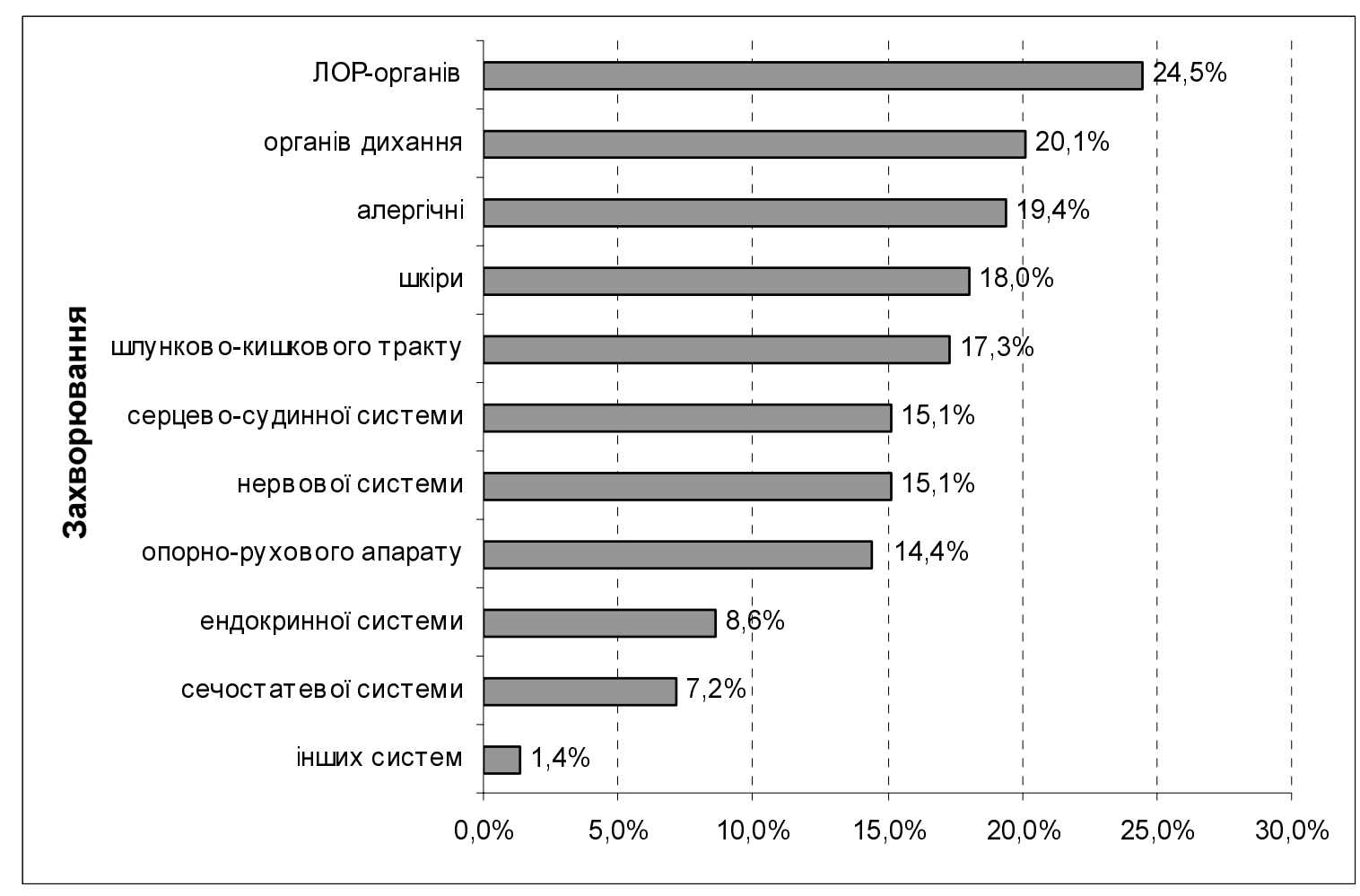

Рис. 3. Точка зору респондентів щодо ефективності методу гомеопатії при лікуванні хронічних захворювань 
валися методом гомеопатії, тоді як 23,0\% $\pm 3,6 \%$ не лікувалися цим методом. Не знають, чи їхні знайомі/колеги по роботі лікувалися гомеопатичними препаратами $13,0 \% \pm 2,8 \%$ респондентів.

Найбільшу/найчастішу ефективність методу гомеопатії при використанні його з метою профілактики відмічають $33,8 \% \pm 4,0 \%$ респондентів, а $17,3 \% \pm 3,2 \%$ респондентів зазначають його ефективність і при лікуванні гострих захворювань $(p<0,05)$.

Точка зору респондентів щодо ефективності методу гомеопатії при лікуванні хронічних захворювань різних органів і систем відображена на рис. 3.

Аналіз відповідей свідчить, що метод гомеопатії найчастіше ефективний при хронічній патології ЛОР-органів (24,5\% $\pm 3,6 \%$ респондентів), органів дихання $(20,1 \% \pm 3,4 \%$ респондентів), алергічних захворюваннях $(19,4 \% \pm 3,4 \%$ респондентів) і захворюваннях шкіри (18,0\% $\pm 3,3 \%$ респондентів).

Ефективність методу гомеопатії при лікуванні хронічних захворювань шлунково-кишкового тракту відмітили 17,3\%ะ3,2\% респондентів. Однакова кількість респондентів - 15,1\% $\pm 3,0 \%$ - відзначила, що метод гомеопатії є ефективним при лікуванні хронічної патології серцевосудинної і нервової систем. Відмітили ефективність гомеопатії при лікуванні хронічних захворювань опорно-рухового апарату $14,4 \% \pm 3,0 \%$ респондентів. Ефективність гомеопатії при лікуванні хронічної патології ендокринної та сечостатевої систем зазначили 8,6\% $2,4 \%$ і 7,2\% $2,2 \%$ респондентів. Підкреслили ефективність методу гомеопатії при лікуванні хронічних захворювань інших систем 1,4\% $\pm 1,0 \%$ респондентів.

Серед причин, які спонукали лікарів до вивчення гомеопатії та використання даного методу у своїй лікарській практиці, було відмічено наступні:

- бажання пацієнтів лікуватися безпечним методом ( $71,4 \% \pm 6,5 \%$ респондентів);

- бажання пацієнтів лікуватися ліками природного походження (46,9\% $7,1 \%$ респондентів);

- побічні дії традиційних лікарських засобів (32,7\% $6,7 \%$ респондентів);
- недостатня ефективність традиційної фармакотерапії (10,2\% 4 ,3\% респондентів);

- доступна ціна ліків $(8,2 \% \pm 3,9 \%)$;

- наявність гомеопатичних препаратів у аптеках $(6,1 \% \pm 3,4 \%$ респондентів).

\section{Висновки}

1. Результати даного соціологічного дослідження свідчать про задоволеність лікарів гомеопатією як методом надання медичної допомоги: респонденти відмічають ефективність цього методу $(88,5 \% \pm 3,4 \%)$, застосовують цей метод у своїй лікарській практиці (56,1\% $4,2 \%)$, а також особисто використовують його для лікування (46,8\% 44,2\%). При цьому лікарі підкреслюють ефективність методу гомеопатії як при лікуванні гострих та хронічних захворювань, так і при застосуванні його з метою профілактики.

2. Задоволеність медичної громадськості та населення методом гомеопатії підтверджена у даному дослідженні широким використанням цього методу серед рідних, близьких та колег респондентів (відповідно 59,0\% 4 ,2\% i $64,0 \% \pm 4,1 \%)$.

3. Результати проведеного соціологічного дослідження свідчать, на нашу думку, про те, що системне впровадження методу гомеопатії може значною мірою сприяти суттєвому підвищенню ефективності, якості, безпечності та доступності медичної допомоги різним категоріям населення. Вирішення проблеми підвищення ефективності та якості медичної допомоги шляхом застосування методу гомеопатії на усіх рівнях їі надання вимагає системних управлінських рішень при умові відповідних науково обґрунтованих заходів щодо їх реалізації.

Перспективи подальших досліджень полягають у дослідженні вітчизняного і міжнародного досвіду щодо організаційних форм застосування методу гомеопатії для підвищення ефективності та якості надання медичної допомоги, а також науковому обґрунтуванні оптимальної функціонально-організаційної моделі інтеграції методу гомеопатії при організації медичної допомоги на всіх рівнях ії надання у період трансформації вітчизняної системи охорони здоров'я.

\section{Список літератури}

1. Вороненко Ю. В. Реформування охорони здоров'я: успіхи і перешкоди / Ю. В. Вороненко, Н. Г. Гойда // Сучасні медичні технології. - 2013. - № 2 (18). - С. 24-26.

2. Гарник Т. П. Сучасний розвиток гомеопатії як методу комплементарної та альтернативної медицини / Т. П. Гарник, Т. М. Козименко, Л. М. Кіркілевська // Фітотерапія. Науково-практичний часопис. - 2008. - № 2. C. 3-8.

3. Гомеопатія і наномедицина: спільне та особливості / Чекман І. С., Мощич О. П., Антонченко В. Я. [та ін.] // Фармакол. та лікарська токсикол. - 2013. - № 2 (33). - С. 21-25. 
4. Горачук В. В. Управління якістю медичної допомоги в закладі охорони здоров'я: [Монографія] / В. В. Горачук. Вінниця : ПП Балюк І. Б., 2012. - 212 с.

5. Гуцол Л. П. Актуальність застосування гомеопатії як холістичного методу в діяльності лікаря загальної практики - сімейної медицини / Л. П. Гуцол, О. П. Мощич // Сімейна медицина. - 2013. - № 4 (48). - С. 112-114.

6. Зіменковський А. Б. Наукове обґрунтування концептуальної моделі управління якістю в охороні здоров'я України шляхом системного розвитку медичної стандартизації : автореф. дис. ... д-ра мед. наук : спец. 14.02 .03 / А. Б. Зіменковський. - К., 2007. - 34 с.

7. Ліщишина О. М. Належна практика створення медичних стандартів як основа для належної клінічної практики / О. М. Ліщишина, А. Б. Степаненко // Укр. мед. часоп. - 2006. - № 3. - С. 21-27.

8. Матюха Л. Ф. Медико-соціальне обґрунтування оптимізації системи первинної медико-санітарної допомоги на засадах сімейної медицини в Україні : автореф. дис. ... на здобуття наук. ступеня д-ра мед. наук : спец. 14.02.03, 14.01.38 / Л. Ф. Матюха. - К., 2011. - 32 с.

9. Мойсеєнко Р. О. Медико-соціальне обґрунтування оптимізації системи надання медичної допомоги дітям і матерям: автореф. дис. на здобуття наук. ступеня д-ра мед. наук: спец. 14.02.03 / Р. О. Мойсеєнко. - К., 2013. $32 \mathrm{c.}$

10. Мощич А. П. Гомеопатия и государственная система здравоохранения (обзор некоторых международных основополагающих аспектов взаимоотношений) / А. П. Мощич, В. А. Туманов // Укр. гомеопатичний щорічник. - 2007. - T. 10. - С. 56-62.

11. Організація соціологічних опитувань пацієнтів, їх представників і медичного персоналу в закладах охорони здоров'я: методичні рекомендації / В. В. Горачук, Ю. В. Вороненко, Н. Г. Гойда [та ін.]. - К., 2012. - С. 21.

12. Попов А. В. Индивидуальность - камень преткновения медицины // Зб. доп. V з'їзду гомеопатів України. K., 2010. - C. 7-13.

13. AlmaAta Declaration 1978 [Electronic resource]. - Retrieved from URL: www.who.int/publications/ almaata_declaration_en. pdf

14. Eames $\bar{S}$. Homeopathic politics / Sara Eames // Simile. The Faculty of Homeopathy Newsletter. - 2010. - Oct. P. 4.

15. Fisher $P$. The science of homeopathy: the current state of play / Fisher Peter // Changing Perceptions: an integrated approach to serious illness. Faculty of Homeopathy. British Homeopathic Congress. - Cambridge, 2010. - P. 41.

16. Nicolai T. Homeopathy as a part of Integrative Medicine - Political developments / Ton Nicolai // The 64th Congress of Liga Medicorum Homoeopathica Internationalis, (Warsawa, 26-30 Aug. 2009): abstract book. - Warsawa (Poland), 2009. - P. 29.

17. Ovretveit J. Каковы оптимальные стратегии управления качества стационарной помощи?: (Доклад сети фактических данных по вопросам здоровья) [Електронный ресурс] / J. Ovretveit; ЕРБ ВОЗ. - Копенгаген, 2003. - 33 с. - Режим доступа: http://www.euro.int/document/e82995r.pdf. - Название с экрана.

18. Thompson E. Prescribing homeopathy for cancer patients - a best case series / Thompson Elizabeth // Changing Perceptions: an integrated approach to serious illness. Faculty of Homeopathy. British Homeopathic Congress. Cambridge, 2010. - P. 32.

19. WHO traditional medicine strategy: 2014-2023. - [Електронний ресурс]. - Режим доступу: http://www.who.int/ medicines/publications/traditional/ trm_strategy 14_23/en/

\section{ГОМЕОПАТИЯ КАК МЕТОД ОКАЗАНИЯ МЕДИЦИНСКОЙ ПОМОЩИ РАЗЛИЧНЫМ КАТЕГОРИЯМ НАСЕЛЕНИЯ: ОЦЕНКА ВРАЧЕЙ}

Н.Г. Гойда ${ }^{1}$, Л.П. Гуцол

${ }^{1}$ Национальная медицинская академия последипломного образования им. П.Л. Шупика, г. Киев, Украина

Винницкий национальный медицинский университет им. Н.И. Пирогова, Украина

Цель: проанализировать мнение врачей относительно эффективности применения гомеопатии при оказании медицинской помощи.

Материалы и методы. Исследование проведено с использованием методов системного подхода и системного анализа и медико-статистического метода. По специально разработанным анкетам были опрошены врачи различных специальностей. Обработано 139 качественно заполненных анкет.

Результаты. Установлена удовлетворенность врачей гомеопатией как методом оказания медицинской помощи. Большинство респондентов отметили эффективность этого метода $(88,5 \% \pm 3,4 \%)$, более половины

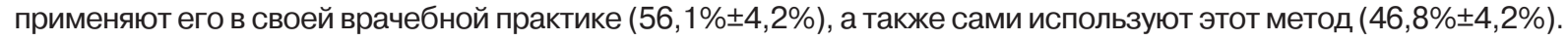
Респонденты указали на эффективность метода гомеопатии как при лечении острых и хронических заболеваний, как и при применении его с целью профилактики.

Выводы. Системное внедрение метода гомеопатии может способствовать существенному повышению эффективности, качества, безопасности и доступности медицинской помощи разным категориям населения.

КЛЮЧЕВЫЕ СЛОВА: социологическое исследование, гомеопатия, врач, эффективность медицинской помощи. 


\section{HOMEOPATHY AS METHOD OF HEALTH CARE GRANTING TO VARIOUS CATEGORIES OF THE POPULATION: EVALUATION OF DOCTORS}

N.G. Hoyda' , L.P. Hutsol'

${ }^{1}$ National Medical Academy of Postgraduate Education named after P.L.Shupik, Kyiv, Ukraine

${ }^{2}$ Vinnytsa National Medical University named after M.I. Pirogov, Ukraine

Purpose: to analyze of doctors opinion on effectiveness of homeopathy application in medical care.

Materials and methods. The study is conducted using of system approach methods, system analysis and medical and statistical method. Under specially developed questionnaires have been surveyed physicians of different specialties. It is processed 139 qualitatively filled questionnaires.

Results. Satisfaction of doctors by homeopathy as method of medical care has been established. Most respondents have noted effectiveness of this method $(88,5 \% \pm 3,4 \%)$, more than half apply it in medical practice $(56,1 \% \pm 4,2 \%)$ as well as themselves using this method $(46,8 \% \pm 4,2 \%)$. Respondents have reported effectiveness of homeopathy as method for the treatment of acute and chronic diseases and application for the preventive purpose.

Conclusions. System implementation of method of homeopathy can promote essential increase of efficiency, quality, safety and availability of medical care to various categories of the population.

KEY WORDS: sociological study, homeopathy, doctor, effectiveness of medical care.

Рукопис надійшов до редакції 06.11.2014

\section{Відомості про авторів:}

Гойда Ніна Григорівна - д.мед.н., проф., проректор з лікувальної роботи Національної медичної академії післядипломної освіти ім. П.Л. Шупика; тел. р/ф: +38(044) 205-49-48.

Гуцол Лариса Петрівна - к.мед.н, доцент кафедри внутрішньої та сімейної медицини Вінницького національного медичного університету ім.М.І. Пирогова; тел. +38(0432) 570360. 